\title{
KARAKTERISTIK SENSORI DAN FISIK KULIT PANGSIT GORENG DENGAN SUBSTITUSI TEPUNG YANG BERBEDA PADA PENYIMPANAN DINGIN DAN BEKU
}

Sensory and Physical Characteristics of Fried Wonton Wrapper with Different Flour Substitution on Cold and Frozen Storage

\author{
Nuri Arum Anugrahati ${ }^{1) *}$, Natania $^{1)}$, Andrew $^{1)}$ \\ ${ }^{1)}$ Jurusan Teknologi Pangan - Fakultas Sains dan Teknologi, Universitas Pelita Harapan \\ Jalan MH. Thamrin Boulevard, Lippo Karawaci Tangerang Banten, 15811 \\ *E-mail: nuri.anugrahati@uph.edu
}

\begin{abstract}
Wonton wrapper is a type of pasta that has a similar composition with noodle, such as wheat flour, water, egg, salt, and kansui. Indonesian people has also consumed wonton wrapper but it has been limited due to the difficulty of wheat flour supply as it's main ingredient. To reduce the dependency of imported wheat flour, this experiment was held to determine tapioca, sago, and glutinous rice as a substitute to wheat flour. The aims of this research were to determine the type of flour to substitute wheat flour in fried wonton wrapper making, to determine the protein percentage of wheat flour in fried wonton wrapper making, and to determine the sensory and physical characteristics of wonton wrapper on cold and frozen storage. This research was conducted by RAL (completely randomized design) using two treatment factors are three kinds of flour (tapioca, sago, and glutinous rice) and three substitution level of concentration (15, 30, and 45\%). The organoleptic result showed that fried wonton wrapper made from medium protein wheat flour with $30 \%$ tapioca flour substitution was the best treatment to produce a good quality since it had a higher crunchiness, acceptance, and substitution level. Sensory and physical characteristics of wonton wrapper has been maintained during 4 weeks of freezing storage.
\end{abstract}

Keywords: fried wonton wrapper, wheat flour, tapioca

\section{PENDAHULUAN}

Pasta merupakan produk pangan olahan dari gandum yang terbuat dari campuran tepung terigu, air, telur, dan garam. Spaghetti, vermicelli, fettucine, dan makaroni merupakan contoh jenis pasta yang telah dikenal oleh masyarakat. Komponen utama dalam pembuatan pasta adalah tepung terigu. Tepung terigu berpengaruh terhadap tekstur pasta $(\mathrm{Fu}$, 2007). Pada umumnya jenis tepung terigu untuk membuat pasta adalah jenis durum semolina karena kandungan glutennya yang tinggi (Howard et al., 2011).

Salah satu jenis produk pangan dengan pasta sebagai bahan dasarnya adalah pangsit. Pangsit merupakan produk pangan dari negara Cina yang sering disebut wonton (Hou, 2010). Wonton terbuat dari tepung, air, telur, garam, dan kansui serta dicetak dengan ukuran 8 - 10 $\mathrm{cm}$ di setiap sisinya dan ketebalan 0,5 - 1 $\mathrm{mm}$. Pada umumnya wonton dapat diisi dengan campuran daging dan sayuran. Secara umum wonton dapat disajikan dengan cara direbus atau digoreng. Di Indonesia wonton dikenal sebagai kulit pangsit.

Beberapa faktor yang dilaporkan mempengaruhi kualitas kulit pangsit adalah kandungan protein dalam tepung terigu, garam, jenis pati, kondisi proses seperti jumlah air yang ditambahkan, lama pengadukan, proses penggorengan, dan pembekuan (Fu, 2007; Tan, 2009). Adonan kulit pangsit yang baik memiliki warna kuning cerah, permukaannya halus, memiliki cooking tolerance, dan tahan terhadap cracking selama pembekuan (Hou, 2010). Pasta yang memiliki kualitas 
fisik dan sensori yang baik dicirikan dengan kemampuan elastisitas dan strength dalam adonan, tensile strength susut masak, kelengketan, dan kekompakan (Howard et al., 2011).

Kulit pangsit dijual di pasaran dalam bentuk beku atau dingin. Pembekuan cepat menghasilkan kualitas produk pasta yang lebih baik daripada pembekuan lambat (Olivera dan Salvadori, 2009). Perubahan kualitas pasta selama penyimpanan erat hubungannya dengan komponen utama dalam formulasi pasta yaitu pati, gluten, dan air (Curti et al., 2015). Substitusi tepung terigu dengan tepung tapioka, sagu, dan beras ketan diharapkan dapat meningkatkan interaksi protein dan pati mengurangi ketergantungan terhadap tepung terigu dalam pembuatan kulit pangsit. Tujuan penelitian adalah menentukan jenis dan konsentrasi tepung tapioka, sagu, dan beras ketan yang menghasilkan karakteristik kulit pangsit terbaik, menentukan kandungan protein terbaik dalam tepung terigu yang menghasilkan karakteristik kulit pangsit terbaik, menentukan karakteristik fisik dan sensori kulit pangsit yang disimpan dingin dan beku.

\section{METODE PENELITIAN}

\section{Alat dan Bahan}

Alat-alat yang digunakan dalam penelitian adalah timbangan, neraca analitik, mixer, pasta maker "Past-a-Fast", roller, gelas ukur, texture analyzer (TAXT Plus), cawan penguapan, oven, desikator, neraca analitik, peralatan destilasi, labu Erlenmeyer, labu lemak, micro Kjedahl, tanur, labu takar, dan cawan pengabuan. Bahan-bahan yang dibutuhkan meliputi tepung terigu "Cakra Kembar", tepung tapioka "Cap Pak Tani", tepung beras ketan "Erawan", tepung sagu "Merbabu", telur ayam negeri, dan garam. Bahanbahan kimia yang dibutuhkan adalah akuades, $\mathrm{NaHCO}_{3}$ 0,3\%, $\mathrm{NaCl}$ 0,3\%, Se,
$\mathrm{K}_{2} \mathrm{SO}_{4}, \mathrm{H}_{2} \mathrm{O}_{2}, \mathrm{H}_{2} \mathrm{SO}_{4}$, asam borat, $\mathrm{NaOH}$, $\mathrm{HCl}, \mathrm{KCl}, \mathrm{AgNO}_{3}$, dan petroleum benzen.

\section{Tahapan Penelitian}

Penelitian dibagi menjadi tiga tahap yaitu tahap pembuatan kulit pangsit dengan variasi jenis dan konsentrasi tepung, tahap pembuatan kulit pangsit dengan variasi kandungan protein tepung terigu, dan tahap penyimpanan kulit pangsit dengan formula terbaik pada kondisi dingin dan beku.

Pembuatan kulit pangsit dengan variasi jenis dan konsentrasi tepung (tahap I)

Tepung terigu, tepung (tapioka, sagu, atau beras dengan masing-masing konsentrasi substitusi 15, 30, 45\%) dicampur dengan telur dan garam. Formula dasar kulit pangsit adalah terigu $100 \%$, telur $55 \%$, dan garam $1 \%$ ). Campuran diaduk sampai adonan menjadi crumbly. Kemudian adonan diisirahatkan selama 10 menit. Adonan dipipihkan menjadi lembaran berukuran $0,5 \mathrm{~mm}$. Selanjutnya di atas lembaran adonan ditaburkan tapioka dan adonan dicetak menjadi bentuk bulat (diameter $5 \mathrm{~cm}$ ).

Pembuatan kulit pangsit dengan variasi kandungan protein tepung terigu (tahap II)

Bahan untuk membuat kulit pangsit adalah terigu dengan kandungan protein 16 dan 20\%, tapioka 30\%, telur, dan garam. Cara pembuatan kulit pangsit sama dengan tahap I.

Pembuatan kulit pangsing dengan formula terbaik yang disimpan dingin dan beku (tahap III)

Bahan untuk membuat kulit pangsit adalah tepung terigu dengan kandungan protein $16 \%$ dan tapioka 30\% (hasil terbaik pada tahap II), telur, dan garam. Cara pembuatan kulit pangsit sama dengan tahap I. Sebelum disimpan pada suhu dingin dan beku selama 4 minggu, kulit pangsit dikemas dalam plastik HDPE. 


\section{Rancangan Penelitian}

Penelitian dirancang dengan Rancangan Acak Lengkap (RAL) yang dibagi menjadi 3 tahap. Faktor yang diuji pada tahap I terdiri atas jenis tepung (tapioka, sagu, beras ketan) dan konsentrasi masing-masing tepung $(15,30$, $45 \%$ terhadap terigu). Faktor yang diuji pada tahap II adalah jenis terigu dengan kandungan protein 16 dan $20 \%$.

\section{Metode Analisis}

Kulit pangsit diuji secara fisik dan organoleptik. Pengujian organoleptik dilakukan dengan metode hedonik dan skoring oleh 70 panelis semi terlatih (Howard et al., 2011). Parameter uji fisik kulit pangsit meliputi pengembangan dan fracturability (Christianty, 2007).

\section{HASIL DAN PEMBAHASAN}

\section{Karakteristik Kulit Pangsit dengan Variasi Jenis dan Konsentrasi Tepung}

Jenis dan konsentrasi tepung yang disubstitusi mempengaruhi kerenyahan kulit pangsit. Subtitusi tepung tapioka $45 \%$ menurunkan kerenyahan kulit pangsit dibandingkan substitusi tepung tapioka $30 \%$ seperti pada Gambar 1. Perbedaan skala kerenyahan kulit pangsit disebabkan oleh jumlah pori-pori yang terbentuk selama penggorengan. Peningkatan konsentrasi substitusi tapioka dari $30 \%$ menjadi $45 \%$ akan meningkatkan jumlah pori sehingga panelis menilai kulit pangsit cenderung rapuh. Hal ini didukung oleh Ediati et al., (2006) yang menyatakan sifat kerenyahan bahan disebabkan oleh terbentuknya pori-pori kosong pada permukaan bahan selama penggorengan yang dilanjutkan dengan penguapan air. Hasil ini berbeda dengan Howard et al., (2011) yang melaporkan tidak ada perbedaan tekstur yang terdeteksi oleh panelis pada pasta yang disubstitusi dengan $30-40 \%$ tepung kacang. Panelis hanya bisa mendeteksi perbedaan tekstur pada pasta yang disubstitusi dengan tepung

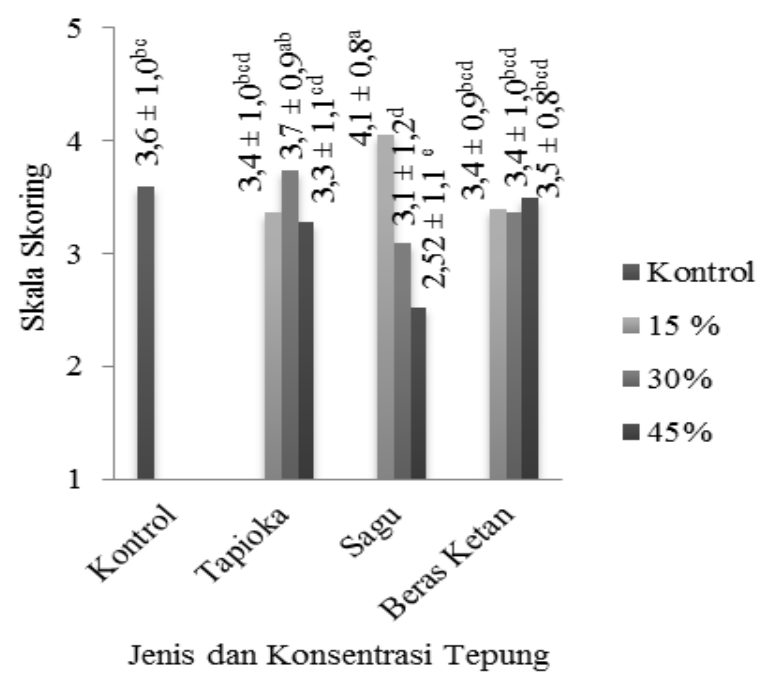

Gambar 1. Pengaruh jenis dan konsentrasi tepung terhadap kerenyahan kulit pangsit goreng dengan skala skoring;

Pangsit yang disubtitusi dengan tepung sagu $15 \%$ memiliki kerenyahan yang tidak berbeda nyata dengan substitusi tepung tapioka $30 \%$. Hal ini diduga berkaitan dengan rasio amilosa dan amilopektin yang hampir sama pada kedua jenis tepung. BeMiller dan Whistler (2009) melaporkan rasio amilosa dan amilopektin tepung sagu dan tepung tapioka berturutturut adalah 27:73 dan 14:86.

Gambar 2 menunjukkan substitusi tepung tapioka dan sagu sebesar $45 \%$ menurunkan tingkat kerenyahan kulit pangsit. Hasil ini berbeda dengan kulit pangsit yang disubstitusi dengan tepung beras ketan. Substitusi beras ketan 15-45\% ternyata tidak menurunkan kerenyahan kulit pangsit. Hal ini kemungkinan berkaitan dengan perbedaan yang lebar pada rasio amilosa dan amilopektin antara tepung tapioka dan tepung sagu dengan tepung beras ketan. Kandungan amilopektin beras ketan dilaporkan lebih tinggi dibandingkan tepung sagu dan tepung tapioka. Beras ketan memiliki kandungan amilosa dan amilopektin dengan rasio 2:98 (BeMiller dan Whistler, 2009). 


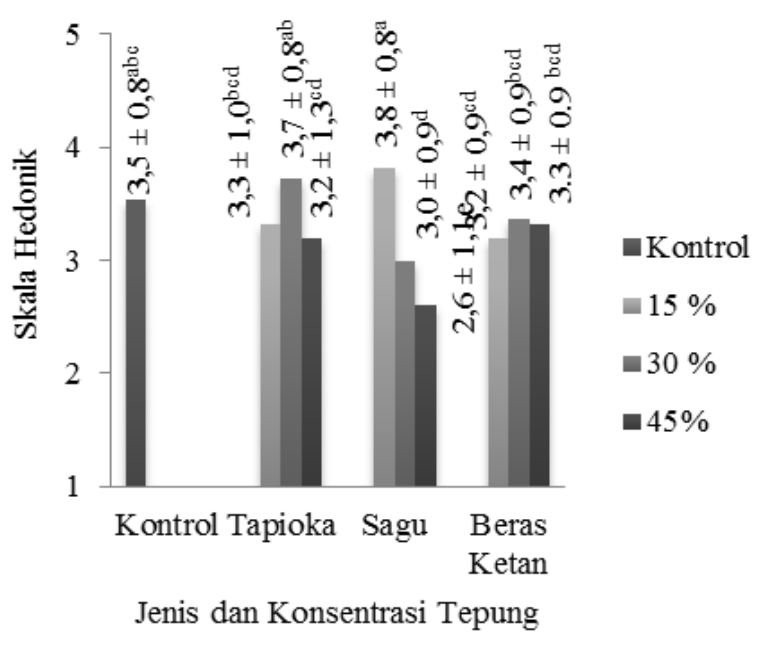

Gambar 2. Pengaruh jenis dan konsentrasi tepung terhadap kerenyahan kulit pangsit goreng dengan skala hedonik

Kulit pangsit yang terbuat dari tepung yang disubstitusi memiliki persentase pengembangan yang lebih rendah daripada kulit pangsit tanpa substitusi seperti terlihat pada Gambar 3. Hal ini disebabkan kulit pangsit tanpa substitusi memiliki matriks gluten yang lebih banyak daripada kulit pangsit yang disubstitusi dengan tepung tapioka, sagu, dan beras ketan. Matriks gluten berperan dalam pengembangan kulit pangsit selama proses penggorengan. Protein gluten akan mengalami denaturasi pada proses penggorengan dan air yang terdapat pada gluten berubah menjadi uap air. Adanya uap air akan mendorong matriks gluten sehingga kulit pangsit mengembang (Gazmuri dan Bouchon, 2009). Lebih lanjut Bonomi et al. (2012) menyatakan kualitas sensori pasta dapat dipengaruhi oleh beberapa faktor seperti polimerisasi protein, gelatinisasi pati, dan interaksi antara protein dan pati.

Pada Gambar 3 terlihat persentase pengembangan kulit pangsit yang disubstitusi dengan tepung tapioka dan sagu lebih tinggi dibandingkan beras ketan. Hal ini juga berkaitan dengan rasio amilosa dan amilopektin tepung tapioka dan sagu yang lebih tinggi daripada tepung beras ketan.

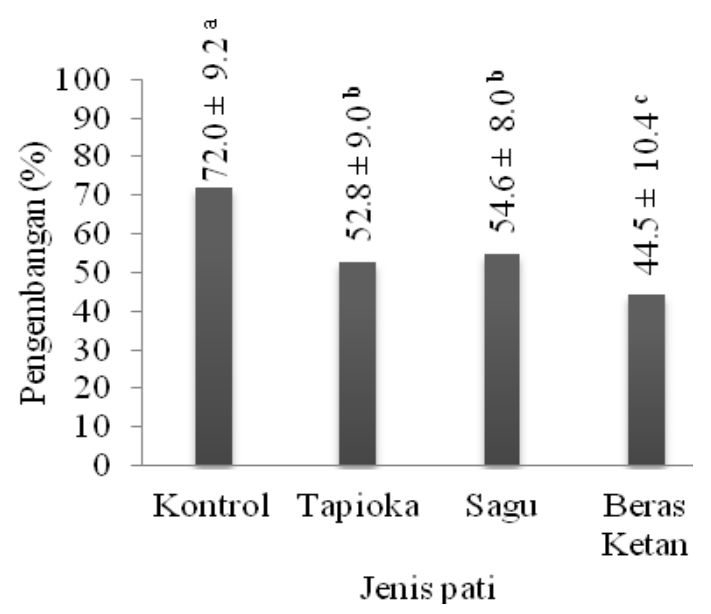

Gambar 3. Pengaruh jenis tepung terhadap persentase pengembangan kulit pangsit goreng

Persentase pengembangan kulit pangsit yang disubstitusi dengan 15-45\% tepung lebih rendah dibandingkan dengan kulit pangsit tanpa subtitusi seperti pada Gambar 4. Hasil ini mendukung Gambar 3 dan menunjukkan bahwa substitusi tepung terigu dengan tepung tapioka, sagu, dan beras ketan akan memberikan persentase pengembangan kulit pangsit yang lebih rendah dibandingkan kulit pangsit tanpa substitusi.

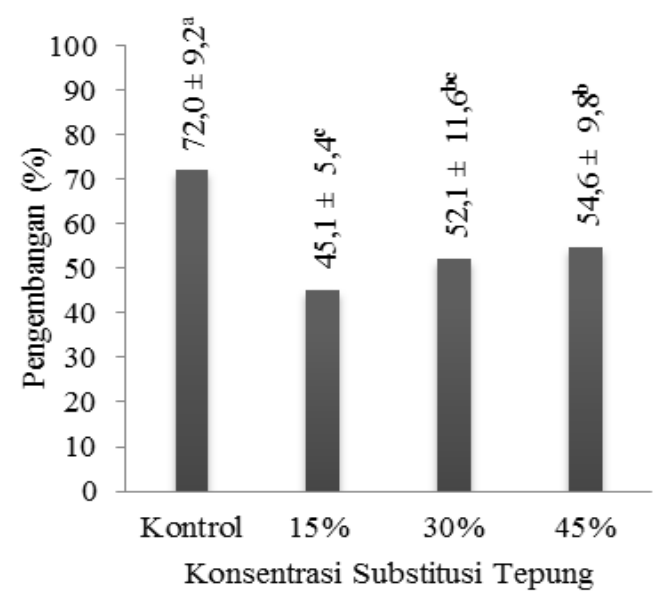

Gambar 4. Pengaruh konsentrasi tepung terhadap persentase pengembangan kulit pangsit goreng

Kulit pangsit tanpa substitusi memiliki nilai fracturability yang tidak 
berbeda nyata dengan kulit pangsit yang disubstitusi dengan beras ketan seperti pada Gambar 5. Substitusi tepung tapioka dan sagu menghasilkan nilai fracturability yang sama dan lebih rendah dibandingkan substitusi beras ketan. Sebagaimana yang dilaporkan $\mathrm{Fu}$ (2007), kandungan protein yang tinggi dapat meningkatkan firmness pasta yang dihasilkan. Selain itu kandungan amilopektin yang lebih tinggi dapat menyebabkan jumlah pori yang lebih sedikit sehingga pasta lebih kokoh. Hasil ini berbeda dengan Sung et al. (2003) yang melaporkan persentase pengembangan pasta akan lebih tinggi pada pasta yang dibuat dari pati dibandingkan dengan pasta yang dibuat dari tepung terigu saja.

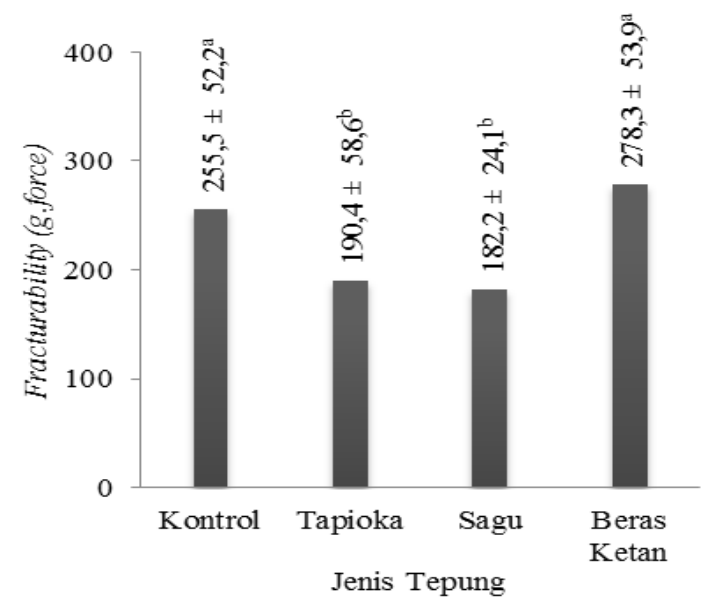

Gambar 5. Pengaruh jenis tepung terhadap fracturability kulit pangsit goreng

Substitusi tepung $30 \%$ dan $45 \%$ memberikan nilai fracturability yang lebih rendah dan berbeda nyata dibandingkan substitusi $15 \%$ dan tanpa subtitusi seperti pada Gambar 6. Hal ini diduga juga dipengaruhi oleh kandungan amilosa dan amilopektin yang lebih banyak dan jumlah pori yang dihasilkan. Hasil ini didukung oleh Hidayat (2008) yang melaporkan parameter tekstur produk pasta berhubungan dengan rasio amilosa dan amilopektin pada tepung.

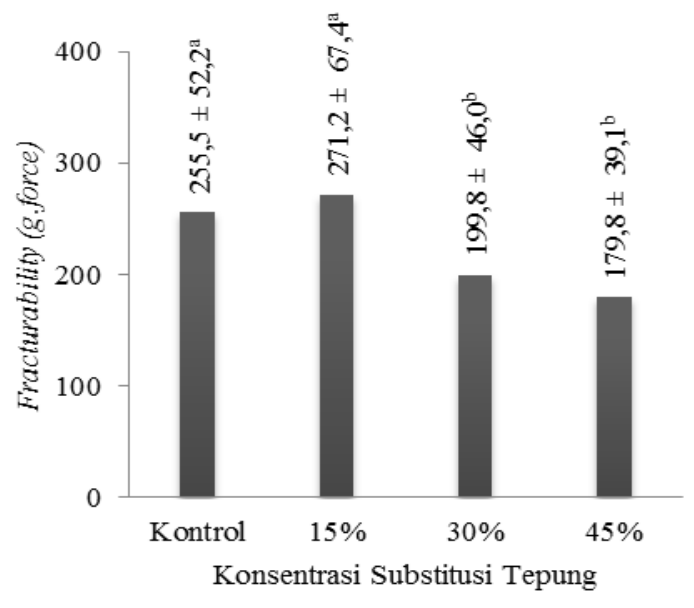

Gambar 6. Pengaruh jenis tepung terhadap fracturability kulit pangsit goreng

Berdasarkan hasil yang diperoleh, maka kulit pangsit yang terbuat dari substitusi tepung tapioka $30 \%$ merupakan kulit pangsit terbaik. Kulit pangsit yang terbuat dari substitusi tepung tapioka 30\% memiliki kerenyahan yang baik secara organoleptik.

\section{Karakteristik Kulit Pangsit dengan Perbedaan Kandungan Protein Tepung Terigu}

Tabel 1 menunjukkan kerenyahan secara skoring dan hedonik serta penerimaan keseluruhan kulit pangsit yang terbuat dari tepung terigu yang memiliki kandungan protein $16 \%$ berbeda nyata dengan tepung terigu yang memiliki kandungan protein $20 \%$. Panelis menilai kerenyahan kulit pangsit yang terbuat dari tepung terigu yang memiliki kandungan protein $16 \%$ lebih tinggi dibandingkan kandungan protein $20 \%$. Hasil ini berbeda dengan Howard et al. (2011) yang melaporkan panelis tidak dapat membedakan tekstur pasta yang disubstitusi dengan tepung kacang sebanyak 30 dan $50 \%$. 
Tabel 1. Karakteristik sensori kulit pangsit yang terbuat dari tepung terigu yang berbeda

\begin{tabular}{cccc}
\hline Kandungan & \multicolumn{3}{c}{ Parameter organoleptik } \\
\cline { 2 - 4 } $\begin{array}{c}\text { protein terigu } \\
(\%)\end{array}$ & $\begin{array}{c}\text { Skoring } \\
\text { kerenyahan }\end{array}$ & $\begin{array}{c}\text { Hedonik } \\
\text { kerenyahan }\end{array}$ & $\begin{array}{c}\text { Penerimaan } \\
\text { keseluruhan }\end{array}$ \\
\hline 16 & $3,7 \pm 0,7^{\mathrm{a}}$ & $3,8 \pm 0,8^{\mathrm{a}}$ & $3,9 \pm 0,7^{\mathrm{a}}$ \\
20 & $3,4 \pm 0,9^{\mathrm{b}}$ & $3,3 \pm 1,0^{\mathrm{b}}$ & $3,5 \pm 1,0^{\mathrm{b}}$
\end{tabular}

Persentase pengembangan dan nilai fracturability tidak berbeda nyata antara kulit pangsit dari tepung terigu yang memiliki kandungan protein $16 \%$ dengan 20\% seperti pada Tabel 2. Perbedaan kandungan protein sekitar $4 \%$ tidak memberikan persentase pengembangan dan nilai fracturability yang berbeda nyata pada kulit pangsit yang terbuat dari tepung terigu yang memiliki kandungan protein $16 \%$ dan 20\%. Walaupun panelis memberikan penilaian kerenyahan yang sama namun persentase pengembangan dan nilai fracturability berbeda. Hal ini menunjukkan bahwa perbedaan kandungan protein $4 \%$ tidak mempengaruhi kerenyahan dan nilai fracturability. Hasil ini berbeda dengan Lai (2001) yang menyatakan penambahan tepung beras yang memiliki kandungan protein lebih tinggi akan menghasilkan nilai hardness yang lebih rendah dibandingkan tepung beras yang memiliki kandungan protein lebih rendah.

Tabel 2. Karakteristik fisik kulit pangsit yang terbuat dari tepung terigu yang berbeda

\begin{tabular}{ccc}
\hline Kandungan & \multicolumn{2}{c}{ Parameter fisik } \\
\cline { 2 - 3 } protein terigu & Pengembangan & Fracturablity \\
$(\%)$ & $(\%)$ & $($ gram force $)$ \\
\hline 16 & $32,6 \pm 10,0^{\mathrm{a}}$ & $251,2 \pm 3,9^{\mathrm{a}}$ \\
20 & $50,8 \pm 16,5^{\mathrm{a}}$ & $244,2 \pm 8,8^{\mathrm{a}}$ \\
\hline
\end{tabular}

Berdasarkan hasil yang diperoleh dapat ditentukan bahwa kulit pangsit yang memiliki karakteristik terbaik adalah kulit pangsit yang terbuat dari tepung terigu 16\%. Selain itu dapat dinyatakan kulit pangsit yang disubstitusi tepung tapioka
$30 \%$ dengan kandungan protein tepung terigu $16 \%$ dipilih sebagai formula dasar kulit pangsit pada tahap selanjutnya.

\section{Karakteristik Kulit Pangsit yang Disimpan pada Suhu Dingin dan Beku}

Kulit pangsit yang disimpan selama 2 minggu memberikan hasil yang tidak berbeda nyata pada semua parameter organoleptik seperti pada Tabel 3. Pada minggu ke-3 dan 4 kulit pangsit tidak dapat diuji secara sensori.

Tabel 3. Karakteristik sensori kulit pangsit yang disimpan pada suhu dingin

\begin{tabular}{cccc}
\hline \multirow{2}{*}{$\begin{array}{c}\text { Minggu } \\
\text { ke- }\end{array}$} & \multicolumn{3}{c}{ Parameter organoleptik } \\
\cline { 2 - 4 } & $\begin{array}{c}\text { Skoring } \\
\text { kerenyahan }\end{array}$ & $\begin{array}{c}\text { Hedonik } \\
\text { kerenyahan }\end{array}$ & $\begin{array}{c}\text { Penerimaan } \\
\text { keseluruhan }\end{array}$ \\
\hline 1 & $3,9 \pm 0,7^{\mathrm{a}}$ & $3,52 \pm 0,9^{\mathrm{a}}$ & $3,7 \pm 0,8^{\mathrm{a}}$ \\
2 & $3,4 \pm 0,8^{\mathrm{a}}$ & $3,42 \pm 0,7^{\mathrm{a}}$ & $3,5 \pm 0,7^{\mathrm{a}}$ \\
3 & TDA $^{*)}$ & TDA $^{*}$ & TDA $^{*}$ \\
4 & TDA $^{*}$ & TDA $^{*}$ & TDA $^{*}$ \\
\hline
\end{tabular}

Pada Tabel 4 terlihat persentase pengembangan dan nilai fracturability kulit pangsit yang disimpan dingin tidak berbeda nyata selama 2 minggu. Hal ini menunjukkan penyimpanan dingin selama 2 minggu tidak memberikan perubahan persentase pengembangan dan nilai fracturability kulit pangsit yang disimpan.

Tabel 4. Karakteristik fisik kulit pangsit yang disimpan pada suhu dingin

\begin{tabular}{ccc}
\hline Minggu ke- & \multicolumn{2}{c}{ Parameter fisik } \\
\cline { 2 - 3 } & $\begin{array}{c}\text { Pengembangan } \\
(\%)\end{array}$ & $\begin{array}{c}\text { Fracturablity } \\
\text { (gram force) }\end{array}$ \\
\hline 1 & $36,2 \pm 5,4^{\mathrm{a}}$ & $228,6 \pm 35,8^{\mathrm{a}}$ \\
2 & $35,2 \pm 4,1^{\mathrm{a}}$ & $240,3 \pm 29,7^{\mathrm{a}}$ \\
3 & TDA $^{*}$ & TDA $^{*}$ \\
4 & TDA $^{*}$ & TDA $^{*}$ \\
\hline
\end{tabular}

Kulit pangsit yang disimpan beku selama 4 minggu tidak memberikan perbedaan pada seluruh parameter organoleptik seperti pada Tabel 5 . Kerenyahan baik secara skoring maupun hedonik dan penerimaan keseluruhan kulit pangsit tidak berbeda nyata selama 4 
minggu. Hal ini menunjukkan panelis memberikan penilaian yang sama terhadap kulit pangsit pada setiap minggu penyimpanan.

Tabel 5. Karakteristik sensori kulit pangsit yang disimpan pada suhu beku

\begin{tabular}{crrr}
\hline \multirow{2}{*}{$\begin{array}{c}\text { Minggu } \\
\text { ke- }\end{array}$} & \multicolumn{3}{c}{ Parameter organoleptik } \\
\cline { 2 - 4 } & $\begin{array}{c}\text { Skoring } \\
\text { kerenyahan }\end{array}$ & $\begin{array}{c}\text { Hedonik } \\
\text { kerenyahan }\end{array}$ & $\begin{array}{c}\text { Penerimaan } \\
\text { keseluruhan }\end{array}$ \\
\hline 1 & $3,6 \pm 0,7^{\mathrm{a}}$ & $3,8 \pm 0,7^{\mathrm{a}}$ & $4,0 \pm 0,6^{\mathrm{a}}$ \\
2 & $3,7 \pm 0,7^{\mathrm{a}}$ & $3,8 \pm 0,6^{\mathrm{a}}$ & $3,9 \pm 0,6^{\mathrm{a}}$ \\
3 & $3,7 \pm 0,4^{\mathrm{a}}$ & $3,9 \pm 0,5^{\mathrm{a}}$ & $4,0 \pm 0,5^{\mathrm{a}}$ \\
4 & $3,8 \pm 0,5^{\mathrm{a}}$ & $3,9 \pm 0,5^{\mathrm{a}}$ & $3,9 \pm 0,7^{\mathrm{a}}$ \\
\hline
\end{tabular}

Karakteristik fisik kulit pangsit yang meliputi persentase pengembangan dan nilai fracturability terlihat pada Tabel 6. Tidak terjadi perubahan persentase pengembangan dan nilai fracturability kulit pangsit setelah disimpan pada suhu beku selama 4 minggu. Hasil ini berbeda dengan Olivera dan Salvadori (2009) yang melaporkan pembekuan menyebabkan perubahan struktur pasta yang meliputi perubahan fisik seperti firmness, elastisitas, water holding capacity pasta dan berdampak pada penerimaan sensorinya.

Tabel 6. Karakteristik fisik kulit pangsit yang disimpan pada suhu beku

\begin{tabular}{ccc}
\hline Minggu ke- & \multicolumn{2}{c}{ Parameter fisik } \\
\cline { 2 - 3 } & $\begin{array}{c}\text { Pengembangan } \\
(\%)\end{array}$ & $\begin{array}{c}\text { Fracturablity } \\
(\text { gram force })\end{array}$ \\
\hline 1 & $42,0 \pm 10,9^{\mathrm{a}}$ & $228,8 \pm 24,6^{\mathrm{a}}$ \\
2 & $28,5 \pm 4,1^{\mathrm{a}}$ & $247,2 \pm 33,3^{\mathrm{a}}$ \\
3 & $36,2 \pm 7,1^{\mathrm{a}}$ & $238,0 \pm 16,1^{\mathrm{a}}$ \\
4 & $33,6 \pm 4,6^{\mathrm{a}}$ & $241,1 \pm 19,9^{\mathrm{a}}$ \\
\hline
\end{tabular}

\section{KESIMPULAN}

Karakteristik terbaik dihasilkan dari kulit pangsit yang dibuat dari tepung terigu yang memiliki kandungan protein $16 \%$ dan disubstitusi dengan tepung tapioka $30 \%$. Kulit pangsit dapat disimpan beku selama 4 minggu tanpa mengalami perubahan nilai fracturability dan kerenyahan secara sensori dan fisik.

\section{DAFTAR PUSTAKA}

BeMiller, J., Whistler, R. 2009. Starch: Chemistry and Technology, Third Edition. Elsevier, London.

Bonomi, F., D’Egidio, M.G., Iametti, S., Marengo, M., Marti, A., Pagani, M.A., Ragg, E.M. 2012. Structure-quality relationship in commercial pasta: A Molecular glimpse. Food Chemistry, 135: 348-355.

Christianty, M. 2007. "Analisa Faktor Daya Kembang dan Daya Serap Krupuk dengan Metode Topsis". Skripsi Sarjana Teknik Industri. Fakultas Teknologi Industri. Universitas Kristen Petra, Surabaya.

Curti, E., Carini, E., Diantom, A., Cassotta, F., Najm, N.E.O., D'Alessandro, A., dan Vittadini, E. 2015. Effect of glycerol and gluten on mechanical properties and ${ }^{1} \mathrm{H}$ NMR mobility of cooked pasta. Food Biophysics, 10: 474-480.

Ediati, R., B. Rahardjo, P. Hastuti. 2006. "Pengaruh Kadar Amilosa Terhadap Pengembangan dan Kerenyahan Tepung Pelapis selama Penggorengan”. Program Studi Ilmu dan Teknologi Pangan, Sekolah Pascasarjana Universitas Gadjah Mada, Yogyakarta.

Fu, B. X. 2007. Asian noodles: History, classification, raw materials, and processing. Journal of Food Research International, 41 (9): 888-902.

Gazmuri, A. M., Bouchon, T. 2009. Analysis of wheat gluten and starch matrices during deep-fat frying. Journal of Food Chemistry 115 (3):999-1005.

Hidayat, B. 2008. Pengembangan Formulasi Produk Mie Berbahan Baku Pati Ubi Kayu. Prosiding. Jurusan Teknologi Pertanian, Politeknik Negeri Lampung, Bandar Lampung.

Hou, G. G. 2010. Asian Noodles. John Wiley \& Sons, Inc., Hoboken. 
Howard, B.M., Hung, Y.-C., McWatters, K. 2011. Analysis of ingredient functionality and formulation optimization of pasta supplemented with peanut flour. Journal of Food Science 76 (1): 40-47.

Lai, H.-M. 2001. Effects of Rice Properties and Emulsifiers on the Quality of Rice Pasta, Journal of the Science of Food and Agriculture, 82: 203-216.

Olivera, D. F., Salvadori, V. O. 2009. Effect of freezing rate in textural and rheological characteristics of frozen cooked organic pasta. Journal of Food Engineering, 90 (2): 271-276.

Sung, W. C., Stone, M. 2003. Characterization of various wheat starch in pasta development. Journal of Marine Science and Technology, 11 (2): 61-69.

Tan, H. Z., Zai G. L., Bin T. 2009. Starch Noodles: History, classification, materials, processing, structure, nutrition, quality evaluating, and improving. Journal of Food Research International, 42 (5-6): 551-576. 